УДК 50 (075.8)

\title{
ОТ «ОБЩЕСТВА РИСКА» ЧЕРЕЗ УСТОЙЧИВОЕ РАЗВИТИЕ К НООСФЕРЕ
}

\section{Попков Владимир Иванович}

к. т. н., доцент

Брянский государственный технический университет

Аннотация: Рассмотрены проблемы перехода человеческой цивилизации от «общества риска» к ноосфере и причины экологического кризиса и других глобальных проблем современной цивилизации. Проанализирована концепция устойчивого развития как возможный вариант сохранения цивилизации. Рассмотрены пути реализации целей устойчивого развития как закономерного этапа эволюции человеческого общества, приближающего преобразование биосферы в ноосферу. Подчеркивается необходимость при реализации целей устойчивого развития системного подхода, предусматривающего институциональные, структурные и технологические преобразования в обществе и экономике (биоцентризм, коэволюция человека и биосферы, оптимизация потребностей, биоэкономика замкнутого цикла, природоподобные технологии и др.).

Ключевые слова: антропогенное воздействие, биосфера, изменение климата, коэволюция, ноосфера, природоподобные технологии, риски, сохранение цивилизации, устойчивое развитие.

\section{FROM «RISK SOCIETY» THROUGH SUSTAINABLE DEVELOPMENT TO THE NOOSPHERE}

\section{Popkov Vladimir Ivanovich}

Abstract: The problems of transition of human civilization from «the risk society» to noosphere and the reasons for the ecological crisis and other global problems of modern civilization are considered. The concept of sustainable development as a possible option for the preservation of civilization is analyzed. The ways of implementing the goals of sustainable development as a natural stage in the evolution of human society, bringing the transformation of the biosphere into the 
noosphere, are considered. The need for a systematic approach, which provides for institutional, structural and technological transformations in society and the economy ( biocentrism, co-evolution of man and the biosphere, optimization of needs, closedcycle bioeconomics, nature-like technologies, etc.), is emphasized .

Key words: anthropogenic impact, biosphere, climate change, coevolution, noosphere, nature-like technologies, risks, preservation of civilization, sustainable development.

В последние годы понятие «безопасность» претерпело существенные изменения и постепенно трансформировалось в более широкое понятие «национальная безопасность». Под национальной безопасностью понимают состояние и условия жизнедеятельности нации, гарантирующие, несмотря на наличие и действие неблагоприятных факторов, ее выживание, свободное, независимое существование, процветание и развитие. Понятие «национальная безопасность» носит многоаспектный, интегрально-системный характер, включает в себя различные виды безопасности - экономическую, социальную, военную, политическую, экологическую, технологическую, информационную и т.д. и т.п., в том числе, как частный случай, безопасность образовательных учреждений. Национальная безопасность - комплекс мер, обеспечивающих защищенность жизненно важных интересов личности, общества и государства во всех сферах их жизнедеятельности от внутренних и внешних угроз и опасностей различного характера.

В настоящее время проблема национальной безопасности тесно связана с общемировой направленностью развития цивилизации в конце XX - начале XXI века, характеризующейся стихийно развертывающимся процессом глобализации. В начале XX века В.И.Вернадский и Э.Леруа указывали, что на смену биосфере в ходе социализации земного природного мира закономерно придет ноосфера, и надеялись на то, что биосфера будет улучшена человеческим разумом и трудом, но сейчас наблюдается иной процесс: техногенное общество разрушает земную биосферную целостность и природотворческие функции биосферы. «Общество не просто глобализуется в мировом масштабе, а качественно изменяется, становится техногенным, переподчиняет в ходе своего развития биосферу, качественно ухудшая и уничтожая ее $»[1]$.

Нынешнюю стадию развития индустриального общества часто называют «обществом риска». Риск становится атрибутом современного нестабильного 
социума $[2,3]$. Степень его неопределенности и неустойчивости начала расти с тех пор, как скорость развития технологий стала превышать скорость осознания человеческим обществом причин и особенно последствий этого развития. Наше общество можно назвать обществом опасностей и катастроф, причем основные опасности сегодня зависят не от природы, а от действий и решений принятых или не принятых человеком. Риск часто непосредственно связан с опасностями современных технологий, которые угрожают планетарной цивилизации, сегодня технико-экологические риски приобретают первостепенное значение. Впервые в истории общество имеет дело с искусственно созданной перспективой самоуничтожения.

Сложившуюся модель развития мирового сообщества после Конференции ООН по окружающей среде и развитию в Рио-де-Жанейро в 1992 г. называют моделью неустойчивого развития. Эта модель чревата опасностями и катастрофами, угрожающими даже всемирным катаклизмом уже в текущем столетии. Она не обеспечивает ни выживания цивилизации, ни сохранения ее природного фундамента - биосферы - и должна смениться новой моделью - моделью устойчивого развития, реализация которой, как полагают ее создатели, позволит разрешить глобальные проблемы, стоящие перед человечеством.

Расцвет индустриального мира в XIX-XX веках нанес сокрушительный удар природной среде, биоте. Сущность мощного давления индустриального и постиндустриального этапов развития цивилизации заключается в невиданных темпах освоения человечеством энергии (пара, электричества, атома) и преобразования вещества [4]. Они оказались разрушительными для окружающей среды.

Достижения науки и техники создали у большинства людей представление об абсолютном превосходстве человека над природой. Космическая и атомная техника, продолжающееся ускорение научнотехнического прогресса, успехи генной инженерии, успехи науки, позволяющие получать вещества, которые не существуют в природе, - все это усилило антропоцентризм (представление о человеке как о центре Вселенной). Люди стали забывать, что они - часть природы, биологический вид, жизнь которого, наряду с социальными факторами, определяется и возможностями природных условий, что все их могущество основано на использовании законов природы, вне которых развитие человеческой цивилизации невозможно. 
«Планета и цивилизация в опасности» - вот один из итогов научнотехнического прогресса [5].

Антропогенное воздействие на биосферу - это однонаправленный процесс изменения в атмосфере, поверхностных водах, почве концентрации основных биогенов - элементов, необходимых для поддержания жизни. Он приводит к быстрому сокращению биоразнообразия, разрушению на огромных площадях экосистем и устойчивых сообществ организмов. Нагрузка, оказываемая человеческой деятельностью на окружающую среду, по мнению академика Н.Н.Моисеева, не просто превращается в фактор, определяющий ее эволюцию, но и растет столь быстро, что говорить о каком-либо равновесии биосферы и одновременно о сохранении гомеостаза вида Homo Sapiens уже не приходится.

Речь идет о нависшей над людьми, человечеством опасности, причина которой заключается в нарушении людьми той критической грани в отношении общества к природе, когда это отношение приводит к ухудшению, к деградации тех природных условий, без которых жизнь человечества становится невозможной. В истории человечества наступил период, когда общество вынуждено четко соизмерять свою активность с возможностями природы. В 60-70-е годы XX века в словесный оборот политиков и ученых вошли словосочетания «глобальный кризис» и «глобальные проблемы». Их появление связано с исследованиями проблем в развитии человечества, выходящих за рамки отдельно взятой страны или группы стран. В результате исследований были выделены четыре общепланетарные или глобальные проблемы, составляющие содержание глобального кризиса:

- Демографическая, связанная с ростом населения планеты.

- Проблема истощения запасов традиционных энергетических ресурсов.

- Проблема истощения запасов сырьевых ресурсов.

- Экологическая проблема, или экологический кризис - проблема загрязнения окружающей среды.

Резкое обострение во взаимоотношениях общества и природы за последние десятилетия привело человечество к глобальному экологическому кризису. Его можно определить как общепланетарное нарушение направленности биосферных геохимических и биологических процессов, могущее привести к появлению биосферы с новыми, патологическими геохимическими свойствами, что сделает ее непригодной для жизни человека. 
Все возрастающие темпы использования природных ресурсов вызвали следующие последствия [6]:

- мощное рассеяние энергии в биосфере вследствие колоссальных размеров использования топливно-энергетических ресурсов;

- колоссальное количество выбросов в атмосферу газов, а в гидросферу - отходов хозяйственной деятельности;

- громадное давление на почвенные ресурсы и биоту в целом вследствие использования удобрений, пестицидов и гербицидов, что привело к деградации почв;

- громадные темпы металлизации биосферы вследствие рассеяния использованных металлов в промышленности;

- появление новых химических, биологических веществ, которых природа никогда не знала и не может утилизировать их без помощи человека.

Нарушение биотической регуляции окружающей среды вследствие разрушения естественных экосистем может привести к выходу за пределы несущей емкости биосферы и повлечь за собой резкие климатические изменения. Антропогенные воздействия на природу (выброс парниковых газов, сведение лесов, уничтожение естественных экосистем и др.) достигли такого уровня, что скорость биологической эволюции уступает темпам климатических изменений, что может привести к разбалансированности климатической системы Земли, росту стихийных бедствий и погодных аномалий.

Растет напряжение в биосфере. По мнению акад. Н.Н. Моисеева, основной причиной кризиса является «принципиальная неустранимость в рамках современной цивилизации рассогласования растущих потребностей растущего населения с возможностями их удовлетворения» [7]. Прогрессирующая неравновесность в соотношении общества и остальной биосферы, разрушение естественных биосферных циклов может привести к глубоким цивилизационным противостояниям. Выход из этой ситуации должен искать сам Homo Sapiens, которого породила Природа. Необходимость осмысления и преодоления сложившейся ситуации поставила экологическую проблему на одно из первых мест в иерархии глобальных проблем современности. Один из крупнейших экологов ХХ века Ю. Одум писал о месте, которое должно занимать цивилизованное человечество в системе природы: «Полное доминирование человека над природой, вероятно, невозможно; оно не было бы ни прочным, ни стабильным, так как человек - очень «зависимый» гетеротроф, который занимает очень «высокое» место в пищевой цепи. Было 
бы гораздо лучше, если бы человек понял, что существует некая желательная степень экологической зависимости, при которой он должен разделять мир со многими другими организмами, вместо того чтобы смотреть на каждый квадратный сантиметр как на возможный источник пищи и благосостояния или как на место, на котором можно соорудить что-нибудь искусственное».

Глобальное измерение, которое приобрела экологическая проблема, обусловлено следующими обстоятельствами:

- объектом антропогенного воздействия стали в той или иной степени все природные оболочки земли - твердая (литосфера), газовая (атмосфера), водная (гидросфера), биотическая (биосфера), космическая;

- экологические проблемы затрагивают прямо или косвенно все страны мира;

- совокупная человеческая деятельность способна коренным образом подорвать природное равновесие биосферы и тем самым привести к гибели человеческую цивилизацию.

Сегодня численность населения планеты составляет около 7.8 млрд человек, к 2050 г., по оптимистическим прогнозам, она вырастет до 9.8 млрд. Ярко выражена нарастающая тенденция урбанизации: предполагается, что к 2050 г. в городах будет проживать более двух третей населения планеты, тогда как сейчас доля городских жителей не превышает 40\% [8]. Урбанизация, развитие промышленности, сельского и лесного хозяйства сопровождаются загрязнением окружающей среды и потерями биоразнообразия. Более 98 \% жизненно важных ресурсов связано с функционированием наземных экосистем. Возрастающие антропогенные нагрузки и потепление климата все в больших масштабах трансформируют наземные экосистемы, а именно их состояние и нормальное функционирование является стратегически важным фактором стабильности и обеспечения человека базовыми ресурсами (воздух, вода, пища). Потребляя ресурсы, человечество, согласно концепции планетарных границ «вышло из зоны комфортной среды обитания по таким параметрам, как климатические изменения, потери биоразнообразия и изменение биогеохимических циклов» [9].

Ключевым фактором развития современной индустриальной цивилизации является энергетика, охватывающая все виды хозяйственной деятельности человека и оказывающая решающее влияние на рост экономики и повышение благосостояния населения. Вместе с тем энергетика относится к основным источникам загрязнения окружающей среды, что привело к деградации среды 
обитания человека, интенсивному разрушению биосферы Земли. Парниковые газы, выбрасываемые в атмосферу в процессе сжигания в энергетических установках угля, нефти и природного газа, вызвали повышение средней температуры атмосферы планеты более чем на $1^{\circ} \mathrm{C}$ по сравнению с доиндустриальным (1850 - 1900) уровнем. Считается, что превышение температурных показателей на $2^{\circ} \mathrm{C}$ может спровоцировать глобальный экологический кризис с непредсказуемыми для человечества негативными последствиями [10]. Вследствие потепления и таяния ледников к 2065 г. среднемировой уровень моря повысится на 24 - 30 см, а к 2100 г. - на 40 - 63 см по сравнению с 1986 - 2005 гг. [8]. В 2015 г. было заключено Парижское соглашение по климату, основная цель которого - не допустить превышения глобальной среднегодовой температуры на планете к 2100 г. более чем на $2^{\circ} \mathrm{c}$ по сравнению с доиндустриальным периодом. Можно отметить, что Парижское соглашение уже привело к необратимой тенденции декарбонизации энергетики: замораживаются угольные проекты и преимущественно развивается безуглеродная энергетика, основанная на возобновляемых источниках энергии.

Как показали исследования последних десятилетий, в системе отношений «человек - природа» природа выступала не пассивным, страдательным партнером. Человеку только казалось временами, что он берет верх над природой, что не природа ему, а он диктует природе свои законы, которым она начинает послушно следовать. Чем дальше развивалась наука, тем чаще она склонялась к выводу, что путь прогресса определяется не навязыванием природе своих желаний. Этот путь требует постижения законов и закономерностей природы, умения ими пользоваться, поскольку человек в своей биологической сути остается частью природы, подчиняется законам биосферы. Известный английский исследователь Г.Кларк писал: «Каждое новое достижение в области культуры усиливало экологическое господство человека: чем больше результатов приносило его вмешательство в естественные процессы, тем чаще нарушал он своей же собственной деятельностью равновесие между собственной культурой и окружающей природой, и тем чаще вследствие этого он был вынужден видоизменять свою экономику, приспособляя ее к новым условиям, созданным его же усилиями. Лучшим примером этого может, пожалуй, служить вырубка лесов, которая способна не только изменить на больших пространствах характер растительной и животной жизни, но и послужить причиной эрозии почв и образования заболоченных, изобилующих комарами дельт, и даже оказать влияние на местный климат. Кем 
бы ни был человек, охотником или земледельцем, деятельность его неизменно приводила к одному результату - он вносил изменения в окружающую природу и устанавливал новые отношения между нею и человеческим обществом».

Деградация природной среды, быстрое снижение качества окружающей среды обостряют проблему сохранения генофонда человека. Нынешний уровень рождаемости детей с генетическими повреждениями достигает $17 \%$. Интерполяция роста генетических повреждений показывает, что если этот процесс и дальше пойдет такими же темпами, то для вымирания людей потребуется лишь несколько поколений, так как генные повреждения у $30 \%$ особей популяции приводят ее к гибели [11]. Быстрое разрушение природной среды подавляет созидательную тенденцию человечества и лишает индустриальное общество перспективы развития.

Человек как биологический вид принадлежит биосфере. Исследования биологов показывают, что заложенные в эволюцию животного мира механизмы постоянной смены видов обеспечивают существование в биосфере одного вида в среднем на протяжении около 3,5 млн лет. Поэтому современный человек кроманьонец, появившийся около 60 тыс. лет назад как биологический вид, находится на начальном этапе развития. Однако своей деятельностью за относительно короткий срок он противопоставил себя биосфере и создал условия для экологического кризиса и собственного уничтожения.

Глобальные проблемы высветили феномен единства и взаимозависимости современного мира, долгое время игнорировавшийся с позиций «классового подхода», противостояния двух систем, хотя многие ученые и политические деятели, представители общественных организаций подчеркивали планетарное распространение экологического кризиса, взаимосвязанность мировых процессов. Уже в 1945 г. в манифесте Рассела-Эйнштейна звучали призывы к глобальному видению мира, отказ от конфронтации: «.... мы выступаем не как представители того или иного народа, континента или вероучения, а как биологические существа, как представители рода человеческого, дальнейшее существование которого находится под сомнением».

Результаты исследований по Международной геосферно-биосферной программе, Международной программе «Человеческие измерения» и российской программе «Глобальные изменения природной среды и климата», по мнению С.А.Пегова, позволяют утверждать, что «в настоящее время природная система Земли находится в точке бифуркации: меняется структура климата и вслед за этим - природные условия во многих регионах планеты... В 
соответствии с теорией катастроф в точках бифуркации любая сложная система проходит так называемый адаптационный период, когда формируются параметры, обеспечивающие новое стабильное (устойчивое) состояние для этой системы. Сложность адаптационного периода в том, что резко сокращаются все характерные времена изменения параметров системы (в обычных условиях эти изменения достаточно монотонные и длительные») [11]. В последнее время резко возросли частота и уровень воздействий, в первую очередь погодных, на человеческий организм в условиях, когда сужены возможности адаптации организма к воздействиям природной среды.

Деградация природной среды влияет на активизацию опасных природных процессов. В 1995-1999 гг. среднее ежегодное число природных катастроф в мире возросло по отношению к 1965-1969 гг. более чем втрое. Материальные потери от природных катастроф оцениваются сейчас примерно в 150 млрд долл.

Осмыслению нарастающих угроз в немалой степени способствовала деятельность Римского клуба - неправительственной международной организации, объединившей около 100 ученых, представителей политических и деловых кругов из различных стран мира. Основанная в 1968 г. итальянским общественным деятелем Аурелио Печчеи, эта организация ставила своей задачей углублять понимание особенностей развития человечества в эпоху научно-технической революции и способствовать привлечению внимания мировой общественности к нарастающему обострению глобальных проблем.

Ученые, входящие в Римский клуб, смоделировали развитие мира с учетом роста численности населения, загрязнения человеком окружающей среды, наличия ресурсов, которыми располагает человечество. Одним из первых и наиболее известных глобальных прогнозов считается исследование «Пределы роста» [12], выполненное под руководством Денниса и Донеллы Медоузов, в котором использовалась математическая модель Дж. Форрестера [13]. В этом прогнозе дана количественная оценка глобальных процессов. Была построена модель развития с учетом населения, территории, природных ресурсов, капиталовложений, производства продуктов питания и загрязнения окружающей среды. Авторы прогноза считали эти параметры и их взаимодействие основными для выяснения динамики мирового процесса. Они рассматривали мир как единое однородное тело, без деления на социалистический и капиталистический лагеря. 
К каким выводам пришли авторы? При сохранении нынешних тенденций развития экономики и роста населения человечество неминуемо столкнется с жесткими пределами, когда уже в течение следующего столетия произойдет экологическая катастрофа глобального масштаба. Авторы рассмотрели несколько вариантов или сценариев развития ситуации, но результаты оказались одинаково негативными. Угроза катастрофы может быть отодвинута, но не далее 2100 года. По мнению авторов прогноза, необходима безотлагательная разработка мер, направленных на поддержание устойчивости мировой системы. Решить эту задачу возможно при достижении экономической и экологической стабильности, глобального равновесия, которое предусматривает нулевые темпы роста населения и производства. На основании этих расчетов, моделей и прогноза появилась теория «нулевого роста». В основу теории положена идея «стабилизации экономики» путем фиксации объемов используемых природных ресурсов, использования сберегающих технологий в производстве. Эта теория подверглась резкой критике как со стороны отсталых стран, не желающих добровольно фиксировать свое отставание, так и со стороны развитых стран.

В 1996 г. соотношение доходов 20\% наиболее богатых жителей планеты (золотой миллиард) и $80 \%$ остальных составляло 4,8 раза. Чтобы поднять уровень жизни $80 \%$ населения планеты до уровня 20\% наиболее богатых, при нынешних технологиях необходимо увеличить объем потребления ресурсов в 20 раз, а с учетом грядущего удвоения населения к 2030 - 2040 годам - в 40 раз, что нереально, т.к. это привело бы к исчерпанию большей части природных ресурсов. Надеяться на то, что за 30 - 40 лет удастся создать технологии, которые в 40 раз сократят потребление ресурсов и энергии, не приходится [5]. Сегодня налицо тупиковая ситуация. Уровень жизни человека напрямую связан с потреблением природных ресурсов, но лишь до тех пор, пока среда сама восстанавливает свои качества. Как только темпы использования природных ресурсов превысили темпы восстановления качества природной среды, человек, чтобы выжить, должен тратить новые ресурсы и энергию на поддержание качества среды обитания за счет уровня жизни.

Другим известным прогнозом Римского клуба был прогноз М.Месаровича и Э.Пестеля [14]. Прогноз базировался на кибернетической модели мира, когда мировая цивилизация описывается как многоуровневая иерархическая система экономических, социальных и политических процессов. Модель этого прогноза была управляема и позволяла включать процесс 
принятия решений. Мир рассматривался не как единое целое, а как система отличающихся, но взаимодействующих регионов (всего десять). Каждый регион описывался системой подмоделей. На основе этой модели были сделаны выводы, в соответствии с которыми миру угрожает не глобальная катастрофа, а последовательная, растянутая во времени серия разнообразных региональных кризисов - экологического, энергетического, продовольственного, демографического, - которые постепенно захватят всю планету. Выход авторы этой модели видели в сбалансированном и дифференцированном развитии различных частей планетарной системы с установлением для каждой жестких параметров на определенный временной интервал. Этот прогноз получил название «органического роста». Эта концепция предлагала развитым странам замедлить свое развитие, а отстающим ускорить.

Глубокие исследования проблем взаимодействия человеческой активности и условий жизни общества были проведены Международным институтом жизни (Institut de la Vie), Они показали, что практически любая форма научно-технической деятельности, если она проводится без достаточного контроля общественности (планетарного гражданского общества, которое еще предстоит создать), грозит катастрофическими последствиями и для организма человека, и для самой биосферы.

Около 40 лет назад А. Печчеи была разработана концепция «нового гуманизма и человеческой революции», поставившая человека в центр развития [15]. Согласно этой концепции, неотъемлемым условием выхода из кризиса должны стать координация усилий и широкое международное сотрудничество всех стран и народов, трансформация системы эгоцентрических государств в единую мировую общность. В 1974 г. акад. Сахаров писал: «... я глубоко убежден, что нет ни одной важной ключевой проблемы, которая имеет решение в национальном масштабе. Только в глобальном масштабе возможно решение основных научно-технических задач современности... Эти задачи требуют многочисленных затрат, непосильных для отдельных государств. Обобщая сказанное, только в глобальном масштабе возможны разработка и осуществление стратегии развития человеческого общества на Земле, совместимой с продолжением существования человечества».

На проходившем в 1990 г. в Москве Глобальном форуме по проблемам окружающей среды и развития в целях выживания проф. Дэвид Сузуки отметил: «Экологическая опасность и ядерная угроза в равной степени 
смертоносны для человечества. Разница лишь в том, что угроза ядерной войны - это все еще угроза, а экологический кризис - реальность».

Английский исследователь Л.Дж. Боттон в книге «Загрязненное небо» писал, что «возможны два варианта выхода из создавшейся ситуации: или люди сделают так, что в воздухе станет меньше дыма, или дым сделает так, что на Земле станет меньше людей».

Таким образом, эпоха индустриального развития человеческого общества, вне зависимости от общественных форм устройства государств, породила проблему новых взаимоотношений хозяйственной деятельности человека и окружающей его природной среды: темпы экономического развития и использования природных ресурсов должны компенсироваться уровнем восстановления качества биосферы в целом. В этих условиях возрастает ответственность науки и ученых перед обществом. Ученые должны предвидеть, что принесет то или иное открытие человечеству и обществу, своевременно распознавать нежелательные последствия своих открытий и новых технологий. Один из ведущих отечественных биохимиков академик В.А.Энгельгардт считал: «Нет сомнения, что в случае глобальных проблем, кризисов ученым не раз придется обращаться к своей совести, призывать чувство ответственности, чтобы найти правильный путь преодоления возникающих угроз. И, разумеется, дело общественной совести ученых мира, общей ответственности - всемерно бороться с причинами, вызывающими вредные, губительные последствия, направлять научные поиски на исправление вреда, который сама наука, не взвесив и не учтя возможных последствий, могла принести, и тем самым оказаться причастной к возникновению тех или иных глобальных проблем».

Человек - составляющая биосферы, он возник в процессе ее эволюции. Развитие любого живого вида, любой популяции, в том числе и человека, может происходить лишь в жестких ограниченных пределах изменения параметров окружающей среды. Н.Н. Моисеев ввел понятие экологического императива как некоторого множества свойств окружающей среды (зависящих от особенностей цивилизации), изменение которых человеческой деятельностью недопустимо ни при каких условиях [16]. Поэтому некоторые виды человеческой деятельности, особенно степень воздействия человека на окружающую среду, должны быть строго ограниченными и контролируемыми. Категория «экологический императив» объективна, она не зависит от воли отдельного человека, а определяется соотношением свойств природной среды и 
физиологических и общественных особенностей человечества. Но реализация этого соотношения зависит от воли человека.

Экономика должна удовлетворять нужды и законные желания людей, но ее рост обязан вписываться в пределы экологических возможностей планеты экологического императива. В отчете ООН «Наше общее будущее» (1987 г.) заявлено [6]: «Человечество способно сделать развитие устойчивым, удовлетворяя нужды настоящего, но при этом не подвергая риску способность будущих поколений удовлетворять свои потребности в ресурсах и окружающей среде».

Именно с этого времени в средствах массовой информации появился термин «устойчивое развитие», под которым понимают такую модель движения вперед, при которой достигается удовлетворение жизненных потребностей нынешнего поколения людей без лишения такой возможности будущих поколений.

Документом первостепенной важности, принятом на конференции в Риоде-Жанейро (1992 г.), явилась Декларация по окружающей среде и развитию. Эта декларация включает 27 рекомендательных принципов, раскрывающих сущность цели движения к устойчивому развитию, соотношение национальных и общечеловеческих интересов, роль государства и различных слоев населения и т.д. Приведем некоторые из них [5]:

- В центре внимания устойчивого развития должны находиться люди. Они имеют право на здоровую и плодотворную жизнь в гармонии с природой.

- Право на развитие должно осуществляться так, чтобы обеспечить равенство возможностей развития и сохранения окружающей среды как нынешнего, так и будущих поколений.

- Для достижения устойчивого развития защита окружающей среды должна стать неотъемлемой частью процесса развития и не может рассматриваться в отрыве от него.

- Для обеспечения защиты окружающей среды государства должны в соответствии с их возможностями шире применять принцип упреждающего принятия мер.

- Все государства и все люди должны объединять усилия с целью решения важной задачи искоренения нищеты как необходимого условия устойчивого развития, чтобы уменьшить разницу в уровне жизни и полнее удовлетворять потребности большей части человечества. 
- Государства должны сотрудничать в духе глобального партнерства, чтобы сохранить, защитить и восстановить здоровье и целостность экосистемы Земли.

- Чтобы достичь устойчивого развития и более высокого уровня жизни всех людей, государства должны ограничить и ликвидировать не соответствующие устойчивому развитию модели производства и потребления и стимулировать соответствующую демографическую политику.

- Устойчивое развитие требует более глубокого научного понимания проблем. Государствам следует делиться знаниями и новыми технологиями для достижения целей устойчивости.

- Экологическая проблема решается наиболее эффективным образом при участии всех заинтересованных граждан. Государства должны развивать и поощрять должное участие населения путем предоставления широкого доступа к экологической информации.

- Война неизбежно оказывает разрушающее воздействие на процесс устойчивого развития. Поэтому государства должны уважать международное право, обеспечивающее защиту окружающей среды во время вооруженных конфликтов, и должны сотрудничать в деле его дальнейшего развития.

- Мир, развитие и сохранение окружающей среды взаимозависимы и неразделимы.

Подводя итоги конференции в Рио-де-Жанейро, ее генеральный секретарь Морис Стронг (Канада) подчеркнул: « Мы выживем только все вместе, в противном случае не выживет никто... Нынешняя экономическая система неадекватна реалиям, надо переходить к эко-экономической системе. Надо уважать суверенитет государств, но надо уважать и целостность биосферы, ее неделимость».

Академик Н.Н. Моисеев считает [17], что концепция устойчивого развития родилась в исследованиях ученых-гуманитариев, прежде всего экономистов, но она не подверглась профессиональному критическому анализу. Локальные мероприятия, намеченные конференцией в Рио-деЖанейро, не способны качественно изменить планетарную экологическую обстановку и существенно снизить риск катастрофического развития событий. Действительность неизмеримо сложнее и опаснее. Политические последствия экологического кризиса, по мнению Н.Н. Моисеева [17], гораздо глубже: «Необходимо дать себе отчет в том, что в результате человеческой деятельности нарушилось естественное равновесие (точнее - квазиравновесие) 
естественных природных циклов, восстановить которое теми методами, которыми мы владеем сегодня, - невозможно. У человечества есть две очевидных альтернативы восстановления равновесия. Либо перейти к полной автотрофности, т.е. поселить человека в некой техносфере, либо уменьшить антропогенную нагрузку на биосферу примерно в 10 раз... ни одна из этих альтернатив не может быть реализована ни сегодня, ни в обозримое время».

Существующих ресурсов явно недостаточно для поддержания стандартов жизни, уже достигнутых в промышленно развитых странах мира. Американский эколог Л. Уайт по этому поводу писал: «Неограниченная эксплуатация ресурсов должна смениться неограниченной изобретательностью ради поддержания постоянного возобновления ресурсов». Поэтому необходима разработка длительной переходной программы изменения общества и окружающей среды, которая должна опираться как на программу технического перевооружения общества (дальнейшего развития технологий, возможно, преимущественно биотехнологий), так и на множество социальных программ образования и переустройства общества, его потребностей, менталитета и выработки некоторого нравственного императива. Н.Н.Моисеев считает [17]: «... пока не поздно, необходимо вложить в понятие «устойчивое развитие» иной смысл, отличный от того, что предлагают политики и экономисты. На самом деле мы должны говорить не об устойчивом развитии, а о Стратегии человечества, его совокупных действиях, способных однажды обеспечить коэволюцию человека и окружающей среды. Ее разработка мне представляется самой фундаментальной проблемой науки за всю историю человечества. Может быть, вся история человеческих знаний, нашей общей культуры всего лишь подготовительный этап для решения этой задачи, от реализации которой зависит и сам факт сохранения в биосфере нашего вида».

Для восстановления гармонии биосферы и человека Н.Н. Моисеев считает необходимым реализацию принципа коэволюции человечества и природы, их совместное развитие, при котором деятельность человека вписывается в естественный биосферный круговорот вещества. По его мнению, термин «устойчивое развитие» можно использовать, если его трактовать поиному - как обозначение стратегии переходного периода, в результате которого может возникнуть режим коэволюции человека и природы. По словам Н.Н.Моисеева, человек должен «не только приспосабливать природу к своим потребностям, но и свои потребности, свою социальную организацию адаптировать к возможностям (и потребностям) природы». Согласно принципу 
коэволюции, человечество должно не только изменять природу, но и само изменяться, приспосабливаясь к природе. Только это позволит обеспечить оптимальное соотношение интересов человечества и биосферы.

В 2015 г. Генеральная Ассамблея ООН утвердила резолюцию «Преобразование нашего мира: повестка дня в области устойчивого развития на период до 2030 года». Среди путей к намеченным целям устойчивого развития и наиболее эффективных ответов на глобальные вызовы названо развитие биоэкономики замкнутого цикла - экономике, которая использует возобновляемые биологические ресурсы суши и моря для производства продовольствия, биоэнергии, биопродуктов и широкого спектра экосистемных услуг [8]. Сотрудники НИЦ «Курчатовский институт» считают, что выход из экологического кризиса возможен лишь путем создания техносферы, базирующейся на природоподобных технологиях, воспроизводящих системы и процессы живой природы в виде технических систем и технологических процессов, интегрированных в естественный природный ресурсооборот [18]. Такие технологии, по их мнению, должны лечь в основу принципиально новой технологической базы цивилизации.

В связи с секвенированием генома человека, успехами, достигнутыми при работе с геномами лабораторных и сельскохозяйственных животных, с неизбежностью встает вопрос об искусственном вмешательстве в геном человека. Наступило время подумать об использовании знаний о геноме человека в практических целях, в первую очередь для лечения различных наследственных заболеваний. $\mathrm{K}$ сожалению, последствия, связанные с манипуляциями с геномом человека, в настоящее время непредсказуемы.

На рубеже тысячелетий возникла еще одна серьезная проблема, имеющая отношение к искусственным манипуляциям с геномом человека, клонирование людей. Эта проблема активно обсуждается различными слоями общества: от рядовых обывателей до парламентов многих стран, от ученых до иерархов церкви. Сегодня клонирование человека вполне осуществимо с помощью уже имеющихся технологий, но здесь главную роль играет этический вопрос.

Очень многое в биологии человека зависит от окружающей среды. Это одна из основных причин, почему полное клонирование человека невозможно. Клоны никогда не будут полностью идентичны своим прародителям [19]. Любой клонируемый организм не наследует гены митДНК своего «родителя», он будет нести митохондриальный геном того организма, который предоставил 
свою яйцеклетку для клонирования. Надежды на то, что с помощью генетической инженерии можно создавать и клонировать людей $\mathrm{c}$ определенными свойствами, пока явно не оправдываются. Самое большое препятствие на пути клонирования человека - неопределенность результата и недостаточная оценка опасностей, возможных в этой процедуре. Клонирование может привести к обеднению генетического фонда человека, повторяя дефекты генома и не давая при этом ему никаких новых качеств [19]. В результате манипулирования с клетками эмбрионов могут появиться человеческие уродцы. Технология клонирования отработана пока только на животных, но и здесь часто возникают многочисленные уродцы, организмы, несущие различные патологии.

Успехи, достигнутые в результате успешного осуществления проекта «Геном человека», одновременно с радужными ожиданиями породили обоснованную большую тревогу как ученых, так и широкой международной общественности. Кроме чисто научных проблем и опасений, возникают многочисленные морально-этические проблемы, связанные с геномом человека, искусственными манипуляциями с ним и клонированием человека. Лауреат Нобелевской премии по физиологии и медицине профессор Жан Доссе предупреждает: «В области генетики человека неразумное использование новых технологий может привести к катастрофическим последствиям».

По инициативе организаторов проекта «Геном человека» было развернуто широкое изучение морально-этических проблем, которые могут возникнуть в связи с секвенированием генома человека и попытками его изменения. Очевидно, что исследования генома человека могут принести как огромную пользу, так и огромный вред для человечества. Необходимо предотвратить малейшую возможность того, «чтобы искусственное вмешательство в геном человека не привело человечество к генетическим «хиросимам» и «чернобылям» [19]. Другая проблема связана с сохранением конфиденциальности наследственной информации каждого человека. В настоящее время различные специалисты занимаются разработкой необходимой законодательной базы. Удалось выработать ряд этических и правовых норм, которые должны предотвратить негативные последствия. В частности, информация о генах определенного индивидуума не может быть передана третьим лицам без его ведома. Конгресс США уже принял ряд законов, запрещающих возможные злоупотребления, связанные с информацией о геноме конкретного человека. Конфиденциальность наследственной 138 
информации каждого человека считается одним из неотъемлемых прав личности. Сегодня сохраняется потребность в разработке международно признанных этических норм, регулирующих искусственное вмешательство в геном человека. Этим активно занимаются международные организации: ЮНЕСКО, ВОЗ, Совет Европы и др. В 1997 г. Генеральной конференцией ЮНЕСКО была принята Всемирная декларация «О геноме человека и правах человека». В ней, в частности, говорится: «Никакое воздействие на геном человека (в научных ли, терапевтических или диагностических целях) не может быть предпринято без строгой предварительной оценки возможных последствий, а также без предварительного свободного согласия заинтересованного лица... Исследования в биологии и генетике влекут за собой особую ответственность, требуют от ученых тщательности, осторожности и интеллектуальной честности». (Цит. по [19]).

Сегодня перед учеными стоят задачи - изучение тончайших механизмов работы генома человека, огромного числа генов и разнообразных генных сетей, всех сложных взаимодействий многочисленных соединений и процессов в клетке, что в конечном итоге должно привести к полному пониманию функционирования клетки и сущности живого. По мнению В.3. Тарантула [19]: «Колоссальные достижения в познании структуры генетического аппарата человека и, в не столь уж далекой перспективе, возникновение подходов к направленному его изменению с новой остротой ставят вечные вопросы: что же такое человек, насколько пластична или, напротив, консервативна его генетическая природа, что можно и что нельзя насильственно менять в нем, какова биологическая опасность искусственных геномных манипуляций для вида гомо сапиенс, не станет ли теперь реальностью целенаправленное изменение человеческой расы, о котором мечтали евгеники? Пока реальных предпосылок к этому не видно, хотя теоретически такую возможность исключить нельзя. При решении подобных вопросов нам приходится полагаться не только на знания, которые открывает наука, но и на то, что мы, люди, считаем морально дозволенным в воздействии на человеческий геном. Думается, что человечеству хватит мудрости и здравого смысла, чтобы обратить в свою пользу результаты, достигнутые в изучении генома человека».

Человечество является составной частью природы. Человек, общество неразрывно с ней связаны и не в состоянии существовать и развиваться вне природы, и в первую очередь без непосредственно окружающей его природной среды. Связь человека с окружающей средой особенно ярко выражена в сфере 
материального производства. Природные богатства служат естественной основой материального производства и жизни общества в целом. Природа является естественной основой жизнедеятельности человека и общества.

Масштабы созданной человеком материальной культуры поистине огромны. И темпы ее развития постоянно увеличиваются. В наши дни так называемая техномасса (все созданное человеком за год) уже на порядок превышает биомассу (вес диких животных и организмов). Уровень воздействия человека на природу зависит в первую очередь от технической вооруженности общества.

Появление научной мысли в биосфере в перспективе неизбежно полностью ее изменяет. В сочетании с трудовой деятельностью человека мысль становится неведомой до этого геологической силой, способной преобразовать вместе с биосферой весь поверхностный слой Земли. Носитель земного разума - человек с нарастающим во времени темпом воздействует на биосферу, активно захватывая все занимаемое ею пространство, окультуривая флору и фауну, меняя облик земной поверхности. В.И. Вернадский определил биосферу как глобальную систему нашей планеты, в которой основной ход геохимических и энергетических превращений определяется живым веществом [20]. По убеждению В.И. Вернадского, преобразование биосферы грядет неизбежно и необратимо.

Современная человеческая цивилизация характеризуется двумя противоположными тенденциями. С одной стороны, усиливается техногенное давление цивилизации на природную среду, на биосферу. С другой - возрастает осознание человечеством ответственности за эволюцию биосферы. Проблема выживания человечества объективно приводит к поиску путей гармоничного сосуществования цивилизации и биосферы - коэволюции человека и биосферы.

Французский философ Э.Леруа в 20-е годы XX века пришел к выводу, что с появлением человека эволюция природы и жизни приобретает качественно новый характер. Человек, наделенный сознанием и разумом, становится условием и орудием дальнейшего поступательного развития всей природы; тем самым совершается переход от биосферы к сфере разума, которую Леруа назвал ноосферой.

Осмысление перспектив коэволюции человека и биосферы привело французского палеонтолога П. Тейяра де Шардена к мысли о возможности появления в будущем некоего коллективного человеческого сознания, которое 
станет контролировать направление коэволюции. В новом состоянии биосфера переходит в сферу разумного взаимодействия человека и природы - ноосферу [21]. По Тейяр де Шардену - ноосфера некий планетарный слой сознания и духовности.

Детально прослеживая пути и этапы развития научной мысли в разные исторические эпохи на разных континентах, В.И. Вернадский обращает внимание на неравномерность этого развития [20]. Но, так или иначе, движение научной мысли идет только вперед. Наука XX в. предстает как одно из ярких проявлений социальной активности человечества. Академик Н.Н. Моисеев писал [7]: «Творческая энергия человека создает все новые и новые биогеохимические циклы, вовлекая в них запасы, накопленные биосферами прошлых тысячелетий и миллионнолетий. Сначала - медь, железо, позднее ископаемые углеводороды. По существу, все технологические цепочки, созданные гением человека, суть новые природные циклы. Они меняют все биосферные ритмы, перекраивают лик Земли, ее ландшафты. К началу ХX века, по выражению В.Вернадского, человечество превратилось в основную геологообразующую силу планеты. В середине XX в. оно начинает вовлекать в кругооборот веществ в природе те запасы радиоактивных элементов, которые Земля получила в момент своего рождения в виде космического тела. Не будет большим преувеличением считать, что ныне рождается новое космическое тело, обладающее совсем новыми свойствами».

В.И. Вернадский назвал трансформированную биосферу ноосферой. Под ноосферой он понимал не выделенный над биосферой «мыслящий пласт», а качественно новое состояние самой биосферы, ее очередную трансформацию в ходе эволюции [20]. « Взрыв научной мысли в XX столетии, - пишет В.И. Вернадский, - подготовлен всем прошлым биосферы и имеет глубокие корни в ее строении. Он не может остановиться и пойти назад. Он может только замедлиться в своем темпе.... Биосфера неизбежно перейдет в ноосферу».

Ноосфера, по Вернадскому, это «качественно новая форма организованности биосферы, возникающая при взаимодействии природы и общества в результате преобразующей мир творческой деятельности человека, опирающейся на научную мысль», такой этап развития биосферы, при котором «проявляется как мощная, все растущая геологическая сила роль человеческого разума и направленного им человеческого труда». 
В настоящее время под ноосферой понимается сфера взаимодействия человека и природы, в пределах которого разумная человеческая деятельность становится главным определяющим фактором развития. В структуре ноосферы можно выделить в качестве составляющих человечество, общественные системы, совокупность научных знаний, сумму техники и технологий в единстве с биосферой. Гармоничная взаимосвязь всех составляющих есть основа устойчивого существования и развития ноосферы.

Ноосфера - это высшая ступень интеграции всех форм существования материи, когда любая преобразующая деятельность человека будет основываться на научном понимании естественных и социальных процессов и органически согласовываться с общими законами развития природы.

Ноосфера - это сфера разумного конструирования сбалансированной системы « биосфера-человек», соответствующей такому обществу, в котором будут обеспечены приоритеты устойчивого экономического развития, нравственного разума, экогуманизма, интеллектуально-информационных ценностей в рамках коэволюции человека и Природы. Идея ноосферы означает, что стихийное развитие цивилизации заканчивается, и сознание начинает определять бытие, т.е. в основе преобразований биосферы с этого времени должен лежать разум.

Концепция ноосферы В.И. Вернадского включает идею автотрофности. Человек, будучи гетеротрофом, зависит от биосферы. С одной стороны, биосфера является источником существования человека, а с другой - объектом разрушительной антропогенной деятельности. Принцип автотрофности был призван разрешить это противоречие. Превращение человечества в автотрофное общество ликвидировало бы его зависимость от биосферы. Создание синтетической пищи из неорганических веществ на основе использования солнечной энергии, по мнению В.И. Вернадского, открывает перед человечеством широкие перспективы в его развитии. Идея автотрофности предполагает изменение естественного круговорота веществ и создание искусственных геохимических циклов. Н.Н. Моисеев считает, что при современном уровне развития науки обеспечить независимость человека от биосферы нереально [17].

Биосфера существовала и до человека. Может существовать и без него. Но человек вне биосферы существовать не может. И, чтобы подчинить своему развитию среду обитания, он должен управлять биосферными процессами, иначе он обречен как обычный биологический вид. Выход из создавшегося 
положения усматривается на основе концепции коэволюционного развития общества и природы. Выполнение принципа совместного развития, обеспечение коэволюции биосферы и общества потребуют от человечества известной регламентации в своих действиях, определенных ограничений.

Человек несет прямую ответственность за дальнейшую эволюцию планеты. Понимание им данного тезиса необходимо и для его собственного выживания. Стихийность в развитии производительных сил сделает биосферу непригодной для обитания людей. Человеку следует соизмерять свои потребности с возможностями биосферы. Воздействие на биосферу должно быть дозировано разумом в ходе эволюции биосферы и общества.

Анализ устойчивости биосферы в работах по оценке последствий ядерной войны, проведенный в 70-80-х годах XX века группой ученых под руководством Н.Н. Моисеева, показал, что устойчивость эта ограничена определенными рамками, переход за которые приведет к новому состоянию биосферы, в котором места человеку может не найтись. Силы человечества настолько выросли, что жизнь на Земле может быть прервана в результате неправильных или злонамеренных действий небольшой группы людей. Подобно тому, как в зрелом и здоровом организме человека все функции, касающиеся взаимодействия организма с внешней средой, координируются головным мозгом, так и функционирование современного глобального сверхорганизма - ноосферы - должно управляться ее совокупным разумом.

« Ноосфера, - писал В.И. Вернадский,- есть новое геологическое явление на нашей планете. В ней впервые человек становится крупнейшей геологической силой. Он может и должен перестраивать своим трудом и мыслью область своей жизни, перестраивать коренным образом по сравнению с тем, что было раньше». В.И. Вернадский выдвинул идею становления ноосферы в качестве главного направления дальнейшего развития человечества, как условие выживания человечества. Первоначально он предполагал, что становление ноосферы - это естественно-исторический процесс, она появится стихийно, как все предшествующие формации и этапы эволюции человечества. Однако сейчас, когда обострились глобальные проблемы, угрожающие гибелью цивилизации, стихийное становление ноосферы становится невозможным. Ноосфера как высокоорганизованное состояние биосферы может реализоваться и существовать при условии, что дальнейший процесс ее развития будет протекать сознательным путем, направляться и организовываться научной мыслью. Это ставит перед учеными 
задачу овладеть в ближайшем будущем методами управления развитием биосферы. Важнейшим условием существования и развития ноосферы, по мнению Вернадского, является единство человечества независимо от деления людей по расовым и национальным признакам. О ноосфере правильнее говорить как об идеале, к которому следует стремиться человечеству.

В настоящее время утверждается точка зрения, что для оптимального ноосферогенеза как планетарного процесса необходимо сохранение биосферы и обеспечение максимально возможной ее естественной эволюции. Именно биосфера является тем фундаментом существования всей жизни на планете и дальнейшего развития разума, если последний создаст механизмы существенного снижения антропогенного давления на природную среду.

А.Д. Урсул отмечает следующие важнейшие черты современного этапа учения о ноосфере [22, 23]:

1. Процесс ноосферогенеза связывается с сохранением биосферы (а не превращением ее в ноосферу) путем снижения антропогенного давления на биосферу почти на порядок, биотической стабилизации и регуляции окружающей среды.

2. Становление ноосферы предполагает реализацию принципа преемственности поколений как выживания и непрерывного развития цивилизации (равенства возможностей поколений людей на планете в удовлетворении своих жизненных потребностей).

3. Включение в орбиту своих исследований процесса глобализации, глобальных проблем.

4. Новое осмысление проблемы обеспечения глобальной безопасности человечества в тесной связи с переходом к устойчивому развитию.

5. Становление ноосферы имеет принципиально планетарный характер.

6. Созидание сферы разума будет сопровождаться усилением роли рационально-справедливых и нравственно-гуманистических ценностей и формированием ноосферной культуры (включающей в себя экологическую культуру и биосферную этику).

7. В процессе ноосферогенеза формируются опережающие механизмы деятельности, в том числе мыслительно-коммуникационной (ноосферный интеллект), управленческой (упреждающее принятие решений и опережающее управление), новой модели образования (ноосферно-опережающего образования), ноосферно-ори-ентированной науки и т.д. 
Переход биосферы в ноосферу возможен путем реализации концепции устойчивого развития в трактовке Н.Н. Моисеева, положив в основу концепции три важнейших принципа [7, 17]:

1. Принцип биосфероцентризма. Переход во взаимоотношении человек - природа от принципа антропоцентризма (предполагающего доминирование человека в отношениях с природой, чисто потребительское отношение к природе, которое неизбежно ведет к экологической катастрофе) к принципу биосфероцентризма (формирование новых духовно-нравственных ценностей человека, направленных на переориентацию центра развития с человека на биосферу в целом).

2. Принцип коэволюции человека и биосферы. Он направлен на обеспечение основных потребностей человека при сохранении адаптационных возможностей естественных экологических систем как на локальнорегиональном, так и на глобальном уровне. Производственная, хозяйственная и социокультурная деятельность людей не должна приводить к деградации естественных экосистем.

3. Принцип оптимизации потребностей. Возможности ресурсного потенциала биосферы ограничены. Поэтому наблюдающийся сейчас интенсивный рост общественных потребностей должен быть существенно ограничен из-за угрозы деградации экосистем. Нормы потребления материальных благ должны быть при этом оптимизированы. Необходимо рациональное сближение норм потребления развитых и развивающихся стран с учетом национальных традиций, природно-климатических особенностей и т.п.

Ноосфера будет представлять (в своем идеальном варианте) социоприродную систему, в которой планетарное опережающее управление реализуется нравственно-справедливым разумом человека и глобальным интегральным интеллектом, формируемым с помощью компьютерных и информационных технологий. Критерием уровня развития и качества жизни в сфере разума станут гуманистические ценности и знания человека, живущего в гармонии с окружающей социальной и природной средой в условиях глобальной всеобщей безопасности.

В политике сегодняшнего дня проблемы выхода из экологического кризиса занимают одно из ведущих мест. Сегодня существуют многочисленные правительственные и общественные организации, оценивающие состояние биосферы, разрабатывающие международные, региональные и национальные научные программы, научно-технические проекты по восстановлению ущерба, 
нанесенного природе, проведению природоохранных мероприятий. Разрабатываются и внедряются новые технологии, направленные на снижение негативного влияния человека на биосферу. Заключаются межгосударственные договоры и соглашения о совместных действиях в области охраны природы и рационального использования природных ресурсов. Эти процессы подтверждают идеи В.И. Вернадского о превращении биосферы в сферу разума.

Естественные науки о живой природе прошли длительный путь развития от наивных представлений античных философов до молекулярной биологии и генной инженерии. На этом пути биология знала времена спада и застоя, которые сменялись подъемом и стремительным взлетом, смелые надежды сменялись сомнениями и разочарованиями.

Важнейшей составной частью биосферы является человеческое общество, а человек - венцом эволюции. Человек оказывает влияние (как правило, негативное) практически на все экосистемы Земли. С точки зрения биологии, человек - биологическое существо, один из видов живой природы. Но психика человека развилась до уровня разума, важнейшей особенностью которого является рефлексия - способность сознания познавать самого себя. Эта способность выделяет человека из всех живых существ.

Глобальные модели и прогнозы развития человеческой цивилизации позволили не только увидеть реальную ситуацию глобального кризиса, но и поставили вопрос о необходимости выработки стратегии дальнейшего развития человечества. Академик Н.Н. Моисеев в книге «Расставание с простотой» так изложил свое видение современной ситуации глобального кризиса [24]: «Постепенно мы начинаем понимать, что общество стоит сейчас на пороге катастрофы, потребующей перестройки всех оснований своего планетарного бытия. Я думаю даже, что мы находимся в преддверии смены характера самой эволюции биологического вида хомо сапиенс. Может быть, даже на пороге нового этапа антропогенеза. Возникающие время от времени академические дискуссии пока еще только фиксируют нарастающее неблагополучие, но они пока очень далеки от раскрытия всей глубины происходящего. А тем более неспособны предложить ему какую-либо альтернативу. Еще никто не рискнул продемонстрировать настоящую правду (хотя многие уже догадываются о ней) во всей ее обнаженной непривлекательности, и мы только подходим к пониманию того, что человечество уже исчерпало тот потенциал своего развития, который оно получило при завершении предыдущего этапа 146 
антропогенеза. Его завершение я связываю с утверждением кроманьонца в качестве единственного претендента на право называться предком современного человека (каким он и оказался на самом деле)... Я совершенно не исключаю фатального исхода человеческой истории».

Знание законов развития живых сообществ, познание причин экологического и других глобальных кризисов, угрожающих цивилизации, позволяют человечеству ориентироваться в выборе пути развития человеческого общества, обеспечивающего выживание как отдельных индивидуумов, так и цивилизации в целом. Концепция устойчивого развития, основанная на принципах биосфероцентризма, коэволюции человека и биосферы и оптимизации потребностей, предполагает переход к новому типу функционирования цивилизации, радикальному изменению исторически сложившихся ориентиров в экономической, социальной, экологической, культурологической и других сферах деятельности человека.

\section{Список литературы}

1. Попкова Н.В. Глобальные проблемы современности и технологическое развитие // Вестник МГУ. Серия "Философия". - 2005. - № 1. - С. 96 - 106.

2. Попков В.И. От "общества риска" к ноосфере // Инновационный вектор развития науки: сб. статей. - Уфа: Аэтерна, 2014. - С. 103 - 110.

3. Popkov V.I. From the "Risk Society" to Sustainable Development // Materials of the International Conference "Process Management and Scientific Developments". (Birmingham, United Kingdom, May 2, 2020). - P. 139 - 145.

4. Дубнищева Т.Я. Концепции современного естествознания: учебник. Новосибирск: ООО «Издательство ЮКЭА», 1997. - 832 с.

5. Воронов В.К., Гречнева М.В., Сагдеев Р.3. Основы современного естествознания. - М.: Высш. школа, 1999. - 247 с.

6. Попков В.И. Концепции современного естествознания. - Брянск: Издво БГТУ, 2019. - 552 с.

7. Моисеев Н.Н. Цивилизация XXI в. - роль университетов // «Alma mater» («Вестник высшей школы»), 2007. - № 5. - С. 36 - 42.

8. Лукина Н.В. Глобальные вызовы и лесные экосистемы // Вестник РАН. - 2020. - Т. 90. - № 6. - С. $528-532$.

9. Крестов П.В., Корзников К.К., Кислов Д.Е. Коренные изменения наземных экосистем в России в XXI веке // Вестник РАН. - 2020. - Т. 90. - № 6. - C. $514-521$. 
10. Акаев А.А., Давыдова О.И. Парижское климатическое соглашение вступает в силу. Состоится ли великий энергетический переход? // Вестник РАН. - 2020. - Т. 90. - № 10. - С. 926 - 938.

11. Пегов С.А. Устойчивое развитие биосферы / / Вестник РАН. - 2007. Т. 77. - № 12. - С. 1069 - 1076.

12. Медоуз, Д.Ч. Пределы роста / Д.Ч. Медоуз, Д.Л. Медоуз, Й. Рэндерс, В. Беренс. - М.: Изд-во МГУ, 1991. - 208 с.

13. Форрестер, Дж. Мировая динамика / Дж. Форрестер. - М.: ООО Издательство АСТ; СПб.: Terra Fantastica, 2003. - 379 с.

14. Mesarovic M, Pestel E. Mankind at the Turning Point. - New York: E.P.Dutton \& Co, 1974. -210 p.

15. Печчеи А. Человеческие качества. - М.: Прогресс, 1980. - 302 с.

16. Моисеев Н.Н. Универсум. Информация. Общество. - М.: Устойчивый мир, 2001. - 200 с. - (Библиотека журнала «Экология и жизнь». Сер. Устройство мира).

17. Моисеев Н.Н. Современный антропогенез и цивилизационные разломы // Вопросы философии. - 1995. - №1. - С. 3 - 30.

18. Ковальчук М.В., Нарайкин О.С., Яцишина Е.Б. Природоподобные технологии: новые возможности и новые вызовы // Вестник РАН. - 2019. Т. 89. - № 5. - С. 455 - 465.

19. Тарантул В.З. Геном человека: Энциклопедия, написанная четырьмя буквами. - М.: Языки славянской культуры, 2003. - 392 с.

20. Вернадский В.И. Биосфера и ноосфера. - М.: Рольф, 2002. - 576 с. (Библиотека истории и культуры).

21. Шарден П. Феномен человека. Преджизнь, жизнь, мысль, сверхжизнь. - М.: Устойчивый мир,2001. - 230 с.

22. Урсул А.Д. Путь в ноосферу. Концепция выживания и устойчивого развития цивилизации. - М.: Луч, 1993. - 275 с.

23. Урсул Д.А., Лось В.А. Концепции современного естествознания. - М.: Изд-во РАГС, 2005. - 440 с.

24. Моисеев Н.Н. Расставание с простотой. - М.: Аграф, 1998. - 480 с.

(C) В.И. Попков, 2021 